This is the final peer-reviewed accepted manuscript of:

Madsen, J. B., Minniti, A., \& Venturini, F. (2018). Assessing Piketty's second law of capitalism. Oxford Economic Papers, 70(1), 1-21.

The final published version is available online at:

https://doi.org/10.1093/oep/gpx040

Rights / License:

The terms and conditions for the reuse of this version of the manuscript are specified in the publishing policy. For all terms of use and more information see the publisher's website.

This item was downloaded from IRIS Università di Bologna (https://cris.unibo.it/)

When citing, please refer to the published version. 


\title{
Assessing Piketty's Second Law of Capitalism
}

\author{
Jakob B. Madsen* Antonio Minniti ${ }^{\dagger}$, Francesco Venturini ${ }^{\ddagger}$
}

May 2, 2017

\begin{abstract}
This paper assesses Piketty's second fundamental law of capitalism to investigate patterns and determinants of wealth inequality over the last century and a half. We first discuss the foundations of this theory on the basis of the most popular growth models, and then perform a long-run regression analysis of wealth inequality using Piketty and Zucman $\mathrm{s}(2014)$ data and a new historical dataset for the OECD countries covering the period $1870-2010$. We find that the wealth-to-income ratio, $\beta$, is significantly related to the ratio between the saving rate, $s$, and the rate of income growth, $g$, between 1870 and 2010, although the estimated coefficient for the $s / g$ ratio falls below the unitary value predicted by the theory. It is also shown that the wealth-to-income ratio responds to the variations in income growth much more than to variations in the saving rate.
\end{abstract}

Keywords: Wealth-to-income ratio; inequality; Piketty's second fundamental law

${ }^{*}$ Jakob B. Madsen, Department of Economics, Monash University, 900 Dandenong Road, Caulfield East, VIC 3145, Australia ${ }^{\dagger}$ Antonio Minniti, Department of Economics, University of Bologna, Piazza Scaravilli n. 2, 40126, Bologna, Italy

${ }^{\ddagger}$ Francesco Venturini, Department of Economics, University of Perugia, via Pascoli 20, 06123, Perugia, Italy \& NIESR, London, UK. 


\section{Introduction}

In his influential book, Capital in the 21st Century, Piketty (2014) advances the thesis that the capital's income share is a declining function of the rate of economic growth because the latter dilutes wealth concentration. Piketty argues persuasively that the productivity slowdown in recent decades has been partly responsible for the increased inequality witnessed in modern capitalist economies. Piketty and Zucman (2014) document that, between 1870 and 2010, the capital-to-income ratio was between 6 and 7 in Europe and between 4 and 5 in the USA. However, during the twentieth century this ratio first decreased, mainly due to the disruptions of world wars and anti-capitalist policies, and then increased rapidly from the $1970 \mathrm{~s} \mathrm{1}^{1}$

The key building blocks of Piketty's theory rest on what he calls the fundamental laws of capitalism. The first is simply an accounting identity which states that, if the capital-to-income ratio, $K / Y$, rises, the share of income accruing to the owners of capital increases, provided that the rate of return on capital, $r$, does not decline. The second law is an equilibrium condition and states that the $K / Y$ ratio tends, in the long run, towards the ratio between $s$ and $g$, where $s$ is the net saving rate and $g$ is the growth rate in net real income.

Piketty's laws have generated great interest among academics and policy-makers, and his theory on capital (or wealth) has been adopted by many as a tool for studying the dynamics of wealth and income inequality in modern economies (see Solow, 2014 or Milanovic, 2014 for a general discussion). However, it has also been subject to much criticism. For example, Acemoglu and Robinson (2015) criticize Piketty's attempt to search for general laws governing capitalism on the grounds that these laws ignore the central role played by political and economic institutions in shaping the evolution of technology and the distribution of resources in a society. Krusell and Smith (2015) criticize the second fundamental law because it implies savings behaviour that is not supported empirically. Furthermore, Piketty assumes that the net saving rate stays constant as growth falls. This assumption requires that the gross saving rate tends to one as $g$ goes to zero, which seems quite implausible. Jones (2015) contends that Piketty's prediction of increasing wealth inequality hinges on the questionable assumptions that changes in $g$ will not be followed by changes in $r$, or that the saving rate net of depreciation is constant over time. Mankiw (2015) argues that, when consumption behaviour, the division of wealth across generations

\footnotetext{
${ }^{1}$ For the US, Saez and Zucman (2016) estimate that, in 2012, the top 0.1\% wealth share had returned to the 1929 level, namely a remarkable $22 \%$, surging from the minimum level of $7 \%$ in 1978 .
} 
and wealth taxation are accounted for, in order for wealth inequality to be steadily increasing (the socalled endless inegalitarian spiral), $r$ should implausibly exceed $g$ by about 7 percentage points annually. Weil (2015) points out that the analysis proposed by Piketty in his book focuses on market wealth and, thus, neglects some dimensions of wealth, most notably human capital and transfer wealth, that have come to constitute a very significant fraction of total wealth over the last 300 years. Another criticism according to Bonnet et al. (2014) is related to the fact that the recent increase in the capital-to-income ratio has been driven predominantly by housing evaluated at market prices rather than at rental prices. This debate has centered on whether the main implications of Piketty's theory can be used for analyzing wealth inequality and, hence, for designing policies aimed at achieving socially desirable levels of wealth (and income) concentration.

This paper contributes to the debate in two respects. First, we provide a discussion of the theoretical foundations of Piketty's second law of capitalism using the most popular growth models (Solow and AK growth models). Second, we adopt this theory to investigate econometrically both the macroeconomic patterns and drivers of wealth inequality since 1870. We use Piketty and Zucman s (2014) original data, which are expressed in net terms (i.e., net of capital depreciation), and a new macro-historical dataset covering a larger set of OECD countries, in which variables are expressed in gross terms, which may help to circumvent possible limitations in Piketty's original data. We estimate a long-run model that accounts for dynamic adjustments in macroeconomic aggregates, for cross-country heterogeneity, and the interdependence that emerges at the global level in the process governing wealth concentration.

As a preview of the results, we find that the wealth-to-income ratio, $\beta$, is significantly related to the saving-to-income growth ratio, $s / g$, between 1870 and 2010, although $\beta$ seems to respond less than proportionally to changes in the $s / g$ ratio, as predicted by the theory. We also find that income growth has been the main determinant of wealth inequality over the very long run (1870-2010). However, since WWII, $g$ has had adverse effects on the accumulation of different capital assets, as it negatively affects the structures/income ratio and positively affects the equipment/income ratio. This implies that the drivers of the wealth-to-income ratio may have been changing over the latest decades.

Thus far, the soundness of Piketty's second law of capitalism, and its usefulness for studying the evolution of income inequality, have remained almost unexplored in the literature. Empirical research on Piketty's laws has predominantly concentrated on Piketty's hypothesis that inequality is an increasing function of the gap between the real returns to assets, $r$, and the growth rate in national income, $g$. 
Acemoglu and Robinson (2015) fail to find any positive impact of the $r$ - $g$ gap on the top $1 \%$ income share for a sample of countries and, in most cases, find a negative relationship. Goes (2016) arrives at almost the same conclusion by finding that capital's share of income is negatively related to the $r-g$ gap for $75 \%$ of the sample countries. Similarly, analysing the determinants of top income shares in the long run for a large sample of countries, Roine et al. (2009) find income inequality to be consistently positively related to per capita income growth.

The present paper is also related to the literature on the determinants of the declining labour income share. Karabarbounis and Neiman (2014) argue that the increasing inequality experienced in most of the world since the early 1980s has been a result of substitution of capital for labour induced by decreasing prices of investment relative to consumer products. This has resulted in an increase in capital's share of income under the often disputed assumption that the elasticity of substitution between capital and labour exceeds one. Using a large panel of countries and industries Bassanini and Manfredi (2014) find that the main forces of labour's declining share of income since the early 1980s have been capital deepening and capital-augmenting technological progress. Checchi and García-Peñalosa (2010) find that the labour market institutions have been crucial for the path of the functional income distribution. Roine et al. (2009) find that financial development, economic growth, and top income taxes have been the most influential determinants of various measures of income inequality. Other influential papers that have investigated the forces behind the trend in the factor income shares are Peretto and Seater (2013), Sturgill (2012, 2014), and Peretto (2015).

The structure of the paper is the following. Section 2 provides a discussion of Piketty's theoretical foundations based on standard growth models. Section 3 presents the econometric model and the estimation procedure used, whilst Section 4 describes the data. Section 5 presents the results. Finally, Section 6 concludes.

\section{Theoretical Setup}

Piketty's theory of wealth inequality is based on the two fundamental laws of capitalism. The first law is an accounting identity and states that the share of capital in national income, $\alpha^{K}$, is

$$
\alpha^{K}=r \times \beta
$$


where $r$ is the net real rate of return on capital, $\beta \equiv K / Y$ is the ratio between the aggregate stock of capital, $K$, and net income, $Y$. The latter is defined as $Y \equiv \hat{Y}-\delta K$, where $\hat{Y}$ is gross income and $\delta$ is the rate at which capital depreciates. In other words, this law states that, for any given rate of return, $r$, the share of income, $\alpha^{K}$, accruing to the owners of capital increases with $\beta$. The second law of capitalism is pivotal as it identifies the key forces behind the evolution of the wealth-to-income ratio. This law is similar to the famous Harrod-Domar-Solow steady-state condition in an economy where growth is driven by capital accumulation. It states that in the long run the capital-to-income ratio, $\beta$, converges to $s / g$, that is (the superscript $S$ stands for Solow)

$$
\beta^{S}=\frac{s}{g}
$$

where $s \equiv \dot{K} /(\hat{Y}-\delta K)$ is the saving rate net of capital depreciation and $g$ is the sum of per capita income growth and population growth.

This formula has different implications in the Harrod-Domar model than in the Solow model. In the Harrod-Domar model, the capital/income ratio is assumed to be constant, implying that a rise in the saving rate leads to a corresponding increase in income. In the Solow model, by contrast, the capital/income ratio is endogenous and converges to a constant in the steady state. Positive (negative) shocks to the saving rate will produce only temporary changes in the rate of capital accumulation and income growth during the transition from the old to the new equilibrium because of diminishing returns to capital. In the new steady-state equilibrium, the $K / Y$ ratio levels off to its optimal (time-invariant) value. In the long run, a rise in the saving rate produces a level effect, but not a growth effect.

Furthermore, in deriving Eq. (1), one could observe that in the Solow model the ratio $K / \hat{Y}$ tends to $\hat{s} /(g+\delta)$ in the steady state, where $\hat{s}$ is the gross savings share of GDP. This is the textbook version of the Solow model which is mathematically equivalent to Piketty's formulation, namely Eq. (1) above. In fact, as discussed in depth by Krusell and Smith (2015), the two formulas are not inconsistent because Piketty defines income not as gross income (that is, GDP) as in the textbook model, but rather as net income (that is, income net of depreciation). Similarly, the saving rate that appears in Piketty's formula is not the gross saving rate - gross saving divided by gross income, but instead it is the net saving rate, i.e., the ratio of net saving (the increase in the capital stock) to net income.

Finally, a crucial insight is that the formula $\beta=s / g$ is not specific to the neoclassical exogenous growth models. As Piketty and Zucman 2014, pp. 272-273) suggest, this formula holds in the steady 
state of a very large set of economic models, including those with an endogenous growth rate. For simplicity of the analysis, in what follows, we derive this condition within the most basic neoclassical endogenous growth framework, i.e., the AK model with an exogenous saving rate. In this model, the production function is linear in the stock of capital, namely $\hat{Y}=A K$, where $A$ is a positive constant representing the economy's level of technology, and the ratio $K / \hat{Y}$ amounts to $1 / A=\hat{s} /(g+\delta)$. This equation is equivalent to Piketty's formulation (the superscript $A K$ stands for AK model)

$$
\beta^{A K}=\frac{K}{Y}=\frac{1}{A-\delta}=\frac{s}{g}
$$

As the $K / Y$ ratio is constant, a rise in the saving rate can only be accommodated by an equivalent increase in the rate of economic growth. Hence, in contrast to the Solow model, in the AK model changes in the saving rate have permanent growth effects. Appendix $\mathrm{A}$ shows that the formula $\beta=s / g$ also holds true in the AK model with optimizing consumers, in which the saving rate is endogenous.

\section{Modelling and Estimation Technique}

The key hypothesis of Piketty and Zucman (2014) is represented by the second law of capitalism, which predicts that the ratio of the saving rate to the economy's growth rate, $s / g$, is the ultimate force behind the capital-to-income, $\beta$, ratio over the long run.

We model the wealth-to-income ratio, Eq. (1), as the following log-linear stochastic specification

$$
\ln \beta_{i t}=\zeta+\theta \cdot \ln (s / g)_{i t}+u_{i t}
$$

where $i$ refers to countries $(i=1, \ldots, N)$ and $t$ to the year of observation $(t=1, \ldots, T)$. $\zeta$ is a constant term, whilst $u_{i t}$ is a stochastic error term whose characteristics will be discussed below. For notational convenience, we express the second law of capitalism as $\beta=s / g$. However, in the empirical analysis, we estimate the empirical model with data expressed in net $\left(\beta=s^{N} / g^{N}\right)$ or gross terms $\left(\beta=s^{G} / g^{G}\right.$ with $g^{G}=g^{N}+\delta$.) Equation (2) assumes a stochastic trend common to all countries, namely that $\theta$ is homogeneous. This law is supported empirically if the estimated elasticity for the saving-to-income growth ratio is unitary, and the constant is statistically insignificant $(\theta=1$ and $\zeta=0)$.

The baseline specification is estimated applying the standard pooled OLS estimator. However, it is 
well-known that this regression approach may be plagued by various econometric issues. First, heterogeneity may exist across countries in the relationship under investigation. We accommodate this issue by including country-specific fixed effects $\left(\zeta_{i}\right)$ and, then, by allowing for heterogeneous slope parameters $\left(\theta_{i}\right)$. Non-zero fixed effects imply that the wealth-to-income ratio systematically differs across countries, irrespective of the impact exerted by the $s / g$ ratio on the dependent variable $\mathrm{L}^{2}$ Parameter heterogeneity may arise because of cross-country differences in tax structure and tax rates, current account balances that create a wedge between investment and saving, the fraction of housing investment in total investment, etc. To address these two forms of heterogeneity, the empirical model is estimated with the fixed effect estimator and with the mean group (MG) estimator developed by Pesaran and Smith (1995) $\mathrm{S}^{3}$

Second, the evolution of the wealth-to-income and the saving-to-income growth ratios may not be independent across countries as these are affected by common shocks (e.g., business cycles, technology shocks, etc.) or share some common trends (e.g., due to globalization). If unaccounted for, crosscountry interdependence may lead to erroneous inferences concerning the impact of the $s / g$ ratio on wealth inequality. We therefore include common time effects that are controlled for through the use of time dummies (i.e., we assume weak cross-sectional dependence), and additionally allow for unobserved common factors (i.e., strong cross-sectional dependence) by including common correlated effects terms (Pesaran, 2006). Failing to account for unobserved factors may yield inefficient estimates if these factors are orthogonal to the regressors, but to biased parameters if these factors and the explanatory variables are correlated. The multifactor structure of the error term of Eq. (2) is therefore modelled as follows

$$
u_{i t}=\zeta_{i}+\lambda_{i} f_{t}+\epsilon_{i t}
$$

where $\zeta_{i}$ are country-specific fixed effects, $f_{t}$ is a latent factor collecting both global and local factors which evolve over time and affect countries to a different extent, $\lambda_{i}$, and $\epsilon_{i t}$ are well-behaved error terms 44 Global factors are shocks involving all countries in the sample, such as globalization, financial development, etc. Local factors are shocks that affect only a subset of countries and/or might vanish more quickly over

\footnotetext{
${ }^{2}$ For instance, Piketty and Zucman (2014) acknowledge that the long-run value of $\beta$ is much higher in Europe than in the US.

${ }^{3}$ The impact of the ratio between $s$ and $g$ may also have changed over the long time interval considered in our regression analysis. Below, we assess the time-varying effect of this variable by estimating $\theta$ over different time spans.

${ }^{4}$ We also include time trends to capture the deterministic time evolution of the data (not modelled here for simplicity).
} 
time. Plugging the expression for $u_{i t}$ into Eq. (2) and assuming heterogeneous parameters we have

$$
\ln \beta_{i t}=\theta_{i} \cdot \ln (s / g)_{i t}+\zeta_{i}+\lambda_{i} f_{t}+\epsilon_{i t}
$$

As Pesaran (2006) documents, unobserved common factors can be proxied by the year-by-year crosssectional average of the dependent variable and regressors, namely $\overline{\ln }_{t}=(1 / N) \sum_{i=1}^{N} \ln \beta_{i t}, \quad \overline{\ln (s / g)} t=$ $(1 / N) \sum_{i=1}^{N} \ln (s / g)_{i t}$. Exploiting this condition, Eq. 3) can be written as (see Eberhardt et al. 2013 )

$$
\ln \beta_{t}=\theta_{i} \ln (s / g)_{t}+\varphi_{1 i} \overline{\ln }_{t}+\varphi_{2} \overline{\ln (s / g)}_{t}+\varphi_{3 i}+\epsilon_{i t}
$$

where $\varphi_{j i}(j=1,2,3)$ is a collection of parameters..$^{5}$ Significance of cross-section mean terms would indicate that there is global interdependence in the process underlying the evolution of $\beta$.

Last but not least, a third issue that may seriously affect the parameter estimates in Eq. (2) is the dynamic behaviour of the variables. To account for dynamics, we express Eq. (3) as an Auto-Regressive Distributed Lags (ARDL) model. Hence, Eq. (3) is modelled as

$$
\ln \beta_{i t}=\eta_{1 i} \ln \beta_{i t-1}+\eta_{2 i} \ln (s / g)_{i t}+\eta_{3 i} \ln (s / g)_{i t-1}+u_{i t} .
$$

The ARDL specification accounts for the persistent nature of the variables and yields consistent estimates for the long-run effect of $s / g$ on $\beta$, irrespective of whether these series are stationary or not. Our analysis of non-stationarity reveals that both $\beta$ and $s / g$ do not contain unit roots, indicating that these variables move around their long-run (stationary) value (see Appendix B $]^{6}$ Even in such a stationary (non-cointegrating) setting, the long-run value of the parameters is inferable from the short-run coefficients estimated with the ARDL model (Chudik et al., 2016). This regression approach, known as the common correlated effects mean group estimator (hereinafter labelled as CCE-MG or CMG), has been proved to be insensitive to simultaneity/reverse causality bias when the lag structure of the variables is well specified (Pesaran and Shin, 1999).

For brevity, below we report only the long-run (country-specific) coefficient for the ratio $s / g$ arising

\footnotetext{
${ }^{5}$ Since $\overline{\ln \beta_{t}}=\bar{\theta} \cdot \overline{\ln (s / g)}_{t}+\bar{\zeta}+\bar{\lambda} f_{t}$, given that $\epsilon_{i t}$ has zero mean, we can express the common factor as a function of the average variables, $f_{t}=(1 / \bar{\lambda})\left(\overline{\ln }_{t}-\bar{\zeta}-\bar{\theta} \cdot \overline{\ln }(s / g)_{t}\right)$, and then include this in Eq. (3). In the resulting equation, the parameters are defined as $\varphi_{1 i}=\lambda_{i} / \bar{\lambda}, \varphi_{2 i}=-\lambda_{i}(\bar{\theta} / \bar{\lambda})$ and $\varphi_{3 i}=\zeta_{i}-\lambda_{i}(\bar{\zeta} / \bar{\lambda})$.

${ }^{6}$ In Appendix B we use the panel statistic associated with the cross-sectionally augmented Dickey-Fuller test devised by Pesaran (2007) for the linear case and by Cerrato et al. (2011) for the non-linear case.
} 
from the estimation of Eq. (5), that is

$$
\theta_{i}=\left(\eta_{2 i}+\eta_{3 i}\right) /\left(1-\eta_{1 i}\right)
$$

Operationally, this procedure estimates the model separately for each individual country including the common correlated effects terms. The sample value of the long-run parameters is obtained by averaging country-specific parameters, $\theta_{i}$. However, it is well-known that MG-type regression procedures may suffer from small sample bias in the presence of a relatively small number of cross-section units. To cater for this possibility, the mean group value of coefficients is obtained by running a robust mean regression on individual CMG parameters following the suggestion of Bond et al. (2010). Below, we report the robust-to-outlier cross-sectional mean of long-run parameters, namely $\theta=\sum_{i=1}^{N} \omega_{i} \theta_{i}$, where the weights, $\omega_{i}$, are higher the closer the observation is to the fit. The significance of $\theta_{i}$ can be evaluated through the $p$-values resulting from the robust mean regression displayed in the tables of results.7

\section{Data}

We use both Piketty and Zucman's (2014) data and a new macro-historical dataset covering a large set of OECD countries over the period 1870-2010. Piketty and Zucman's (2014) data contain extensive information on the structure of wealth, saving, and investment, allowing one to trace the dynamics of private capital accumulation, public debt, and net foreign asset positions since the nineteenth century for France, Germany, the UK and the USA. Piketty and Zucman (2014) are interested in studying the evolution of the wealth-income ratio and the role played by price and volume components, and, hence, they express wealth and its components at market prices net of capital depreciation.

Piketty and Zucman (2014) assume that capital is synonymous with wealth. They define national wealth, $W_{n t}$, as the sum of private and public wealth, $W_{n t}=W_{t}+W_{g t}$. Private wealth, $W_{t}$, is the net wealth (assets minus liabilities) of households and non-profit institutions serving households. Public wealth, $W_{g t}$, is defined as the net wealth of public administration and government agencies and consists of public land plus fixed capital minus government net debt. National wealth can also be decomposed into domestic capital and net foreign assets: $W_{n t}=K_{t}+N F A_{t}$. A crucial difference between the data

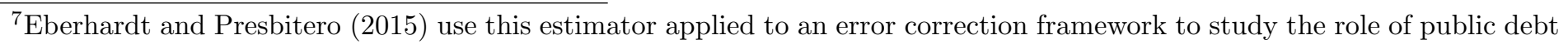
on economic growth in a global sample of countries. Eberhardt and Teal (2011) discuss extensively the heterogeneity issue for the macroeconomic analysis of growth and development. 
used by Piketty and Zucman (2014) and our data is that these authors assess capital by means of the stock market capitalization of the company, while our capital data is in acquisition costs. Pros and cons of these two alternative procedures are discussed in Piketty and Zucman (2014, p. 1265). Net national income, $Y_{t}$, and its growth rate, $g^{N}$, are measured net of depreciation and defined as the sum of net domestic output and net foreign income, $Y_{t}=Y_{d t}+r N F A_{t}$. The national and private saving rate, $s^{N}$, is measured net of depreciation.

Our macroeconomic dataset contains information on income (GDP), savings, and non-residential capital assets and is collected from national and international sources. Unlike Piketty and Zucman (2014), our data are expressed in gross terms and at constant prices, and cover 21 countries (Australia, Austria, Belgium, Canada, Denmark, Finland, France, Germany, Greece, Ireland, Italy, Japan, Netherlands, New Zealand, Norway, Portugal, Spain, Sweden, Switzerland, the UK and the US). In this dataset, capital includes only non-residential structures and equipment and, hence, is narrower than the notion of wealth used by Piketty. As discussed above, as our dataset is in gross terms, the second law of capitalism uses a measure of income growth gross of capital depreciation, $g^{G}$ (with $g^{G}=g^{N}+\delta$ ). $\delta$ is assumed to be time-invariant and is set equal to 0.08 when using a measure of $\beta$ based on total capital, and to 0.17 and 0.03 when $\beta$ is based on equipment and structures. We use a measure of gross saving rate, denoted as $s^{G} 8$

\section{Results}

\section{Baseline Framework}

The results of regressing Eq. (5) are shown in Table 1. These estimates are based on fully homogeneous parameters. The top panel of the table uses Piketty's data, which cover 4 countries for a total of 540 time observations. These estimates are obtained using both national and private sector data. Estimates in the lower panel use our data and include 21 countries with a total of 2,983 observations. Our saving data refer to the private sector of the economy. The table reports the long-run coefficients yielded by

\footnotetext{
${ }^{8} \mathrm{~A}$ detailed Data Appendix supplementing the paper by Piketty and Zucman, 2014) is available at: $<$ http://piketty.pse.ens.fr/en/capitalisback>. Detailed information about sources underlying our dataset and related data construction is provided in the Online Appendix to this article. To estimate the model in logs, a minimum constant is added to ensure that all values are positive (see Madsen, 2016).
} 
regressing the ARDL model displayed in Eq. (5) and the associated $p$-value of significance $9^{9}$

In col. (1), Table 1, we adopt the pooled OLS estimator without accounting for the effects of common shocks. Using the original data from Piketty and Zucman (2014) we find that the wealth-to-income ratio is significantly related to the $s / g$ ratio, regardless of whether national or private sector data are used. The estimated coefficients are quite similar (0.177 and 0.165$)$ but, nonetheless, fall below the unitary value suggested by the theory. This indicates that $\beta$ varies less than proportionally to the $s / g$ ratio. This finding is neither related to the nature of the variables that are evaluated at market prices by Piketty and Zucman (2014), nor to the small number of countries in their dataset. Indeed, a consistent result arises when we estimate the empirical model using our dataset, with which we find a coefficient of 0.103.

In col. (2), we introduce a set of time dummies to control for the effects of common shocks. Accounting for temporary shocks is crucial especially when one expresses variables at market prices, as the latter may change relatively rapidly over time and hence bias the estimates. It is interesting to observe that the long-run elasticity estimated for the ratio between the saving rate and income growth is higher with either set of data when time dummies are included in the regressions. Nonetheless, the coefficients for the explanatory variable remain well below unity.

In col. (3) we add fixed effects on the presumption that each country has its own steady-state value for the wealth-to-income ratio. This may be due to the (time-invariant) effect of omitted variables that influence the wealth-to-income ratio differently across countries and create a wedge between $K / Y$ and $s / g$. Using data from Piketty and Zucman (2014), fixed effects estimates show that the impact estimated for the $s / g$ ratio is 0.147 when using national data, whereas the explanatory variable turns out to be insignificant with the data for the private sector. By contrast, the result based on our set of twenty-one countries of 0.140 is perfectly consistent with the values shown in col. (2).

\section{Global Interdependence and Cross-Country Differentials}

A clear implication of our results is that the impact of the ratio between the saving rate and income growth on $\beta$ is less than unitary. This finding has been shown to be unrelated to the nature of the data (evaluated at market prices or acquisition costs) and to the presence of common time effects (weak cross-sectional dependence). In what follows, we address three potential concerns about the robustness

\footnotetext{
${ }^{9}$ Following Chudik and Pesaran (2015), the criterion $T^{1 / 3}$ is used to choose the lag order of the variables. Hence, five-year lags are used in the analysis over the period 1870-2010, whilst four- and three-year lags are used in the regressions in which the periods are restricted to 1945-2010 and 1970-2010. The results are quite insensitive to the choice of lags.
} 
Table 1: Relationship between $\beta$ and $s / g$ : 1870-2010

Baseline estimation (long-run parameters)

\begin{tabular}{|c|c|c|c|}
\hline & 1 & 2 & 3 \\
\hline & \multirow{2}{*}{\multicolumn{3}{|c|}{$\begin{array}{c}\text { Piketty \& Zucman data (4 countries, } 540 \text { obs) } \\
\text { National }\end{array}$}} \\
\hline & & & \\
\hline \multirow[t]{2}{*}{$\ln s / g$} & $0.177^{* *}$ & $0.101^{* * *}$ & $0.147^{* *}$ \\
\hline & {$[0.011]$} & {$[0.008]$} & {$[0.050]$} \\
\hline \multirow[t]{2}{*}{ Constant } & 0.07 & 0.545 & 0.55 \\
\hline & {$[0.474]$} & {$[0.110]$} & {$[0.108]$} \\
\hline \multirow{3}{*}{$\ln s / g$} & \multicolumn{3}{|c|}{ Private } \\
\hline & $0.165^{*}$ & $0.19^{* * *}$ & 0.111 \\
\hline & {$[0.072]$} & {$[0.000]$} & {$[0.143]$} \\
\hline \multirow[t]{2}{*}{ Constant } & 0.02 & 0.394 & 0.47 \\
\hline & {$[0.838]$} & {$[0.241]$} & {$[0.167]$} \\
\hline & \multicolumn{3}{|c|}{ Our data (21 countries, 2963 obs) } \\
\hline & \multicolumn{3}{|c|}{ Private } \\
\hline $\ln s / g$ & $0.103^{*}$ & $0.144^{* *}$ & $0.140^{* * *}$ \\
\hline & {$[0.053]$} & {$[0.011]$} & {$[0.000]$} \\
\hline \multirow[t]{2}{*}{ Constant } & $-0.072^{* *}$ & $0.284^{* *}$ & $0.240^{*}$ \\
\hline & {$[0.021]$} & {$[0.044]$} & {$[0.090]$} \\
\hline Method & OLS & OLS & $\mathrm{FE}$ \\
\hline Cross-sectional dependence & No & $\mathrm{TD}$ & $\mathrm{TD}$ \\
\hline
\end{tabular}

Notes: The long-run parameters $(\theta)$ are derived from the ARDL specification (with logged variables). All regressions include country-specific time trends and five lags of the variables. Piketty and Zucman (2014) express wealth at market prices, $s$ and $g$ in net values $\left(s^{N}\right.$ and $\left.g^{N}\right)$. Our data are expressed at constant prices and in gross terms $\left(s^{G}\right.$ and $\left.g^{G}\right)$; income growth is defined as $g^{G}=g^{N}+\delta$ with capital depreciation, $\delta$, set to 0.08 . $p$-values in brackets. $* * *, * *, *$ indicate significance at 1,5 and $10 \%$, respectively.

of our previous results (see Table 2 for the estimates). First, we allow for the possibility of cross-country linkages and consider strong interdependence across economies. This may be the result of unobserved common factors that induce wealth inequality to co-vary globally. Second, we allow for cross-country heterogeneity in the impact of the $s / g$ ratio on wealth inequality. Finally, we investigate whether the wealth-to-income ratio varies over time mainly as a reflection of the dynamics in the saving rate or in that of income growth.

In cols. (1)-(3), we include common correlated terms within the fixed effects specification to assess whether our previous findings are influenced by unobserved common factors. In line with Eberhardt et al. (2013) we allow for heterogeneity in the impact of CCE terms and interact the latter variables with country dummies 10 Allowing for these interaction terms results in a decline in the long-run coefficient

\footnotetext{
${ }^{10}$ Long-run coefficients of the CCE terms are derived as a combination of the short-run parameters derived from the ARDL regression.
} 
of the $s / g$ ratio compared to the estimates in Table 1. This suggests that $\beta$ responds to the global (cross-country) movements in wealth inequality and in the $s / g$ ratio, as a result of an array of factors such as the international mobility of capital and labour inputs, policy coordination, trade agreements, etc.

As a second step of analysis, in cols. (4)-(6), we estimate country-specific regressions, enriched with CCE terms, and compute the robust-to-outliers mean of parameters $\theta_{i}$ (CMG regression). The estimates using our sample are robust to this consideration (0.069 in col. 6 vs 0.071 in col. 3). Results based on Piketty and Zucman's (2014) data are similar in terms of coefficient size, but lose some explanatory power in terms of statistical significance, probably due to the low degrees of freedom in computing the mean group values $(n=4)$. Indeed, only in the regression using private data is the coefficient of the $s / g$ ratio, in net terms, significant but only at the $10 \%$ level. The weak explanatory power of the ratio between the saving rate and income growth in the estimation based on national data is likely to be driven by the large heterogeneity in the dynamics of public wealth/debt across countries, justifying the need to separate out national wealth from private wealth, as Piketty and Zucman (2014) suggest.

\section{Table 2: Relationship between $\beta$ and $s / g$ : 1870-2010}

$$
\text { ARDL estimation (long-run parameters) }
$$

\begin{tabular}{|c|c|c|c|c|c|c|c|c|c|}
\hline & (1) & (2) & (3) & (4) & (5) & (6) & (7) & (8) & (9) \\
\hline & \multicolumn{2}{|c|}{ Piketty \& Zucman's data } & Our data & \multicolumn{2}{|c|}{ Piketty \& Zucman's data } & Our data & \multicolumn{2}{|c|}{ Piketty \& Zucman's data } & Our data \\
\hline & $\begin{array}{c}\text { National } \\
\text { wealth/ } \\
\text { Income } \\
\text { (Net) } \\
s^{N} / g^{N}\end{array}$ & $\begin{array}{c}\text { Private } \\
\text { wealth/ } \\
\text { Income } \\
\text { (Net) } \\
s^{N} / g^{N}\end{array}$ & $\begin{array}{c}\text { Total } \\
\text { capital/ } \\
\text { GDP } \\
(\text { Gross }) \\
s^{G} /\left(g^{N}+\delta\right)\end{array}$ & $\begin{array}{c}\text { National } \\
\text { wealth/ } \\
\text { Income } \\
\text { (Net) } \\
s^{N} / g^{N}\end{array}$ & $\begin{array}{c}\text { Private } \\
\text { wealth/ } \\
\text { Income } \\
\text { (Net) } \\
s^{N} / g^{N}\end{array}$ & $\begin{array}{c}\text { Total } \\
\text { capital/ } \\
\text { GDP } \\
(\text { Gross }) \\
s^{G} /\left(g^{N}+\delta\right)\end{array}$ & $\begin{array}{c}\text { National } \\
\text { wealth/ } \\
\text { Income } \\
\text { (Net) } \\
s^{N} / g^{N}\end{array}$ & $\begin{array}{c}\text { Private } \\
\text { wealth/ } \\
\text { Income } \\
\text { (Net) } \\
s^{N} / g^{N}\end{array}$ & $\begin{array}{c}\text { Total } \\
\text { capital/ } \\
\text { GDP } \\
(\text { Gross }) \\
s^{G} /\left(g^{N}+\delta\right)\end{array}$ \\
\hline $\begin{array}{l}\text { Dependent variable: } \ln \beta \\
\ln s / g\end{array}$ & $\begin{array}{c}0.078^{* * *} \\
{[0.007]}\end{array}$ & $\begin{array}{c}0.035^{* *} \\
{[0.030]}\end{array}$ & $\begin{array}{c}0.071^{* * *} \\
{[0.000]}\end{array}$ & $\begin{array}{l}0.0602 \\
{[0.252]}\end{array}$ & $\begin{array}{l}0.046^{*} \\
{[0.064]}\end{array}$ & $\begin{array}{c}0.069^{* * *} \\
{[0.004]}\end{array}$ & & & \\
\hline $\begin{array}{l}\ln s \\
\ln g\end{array}$ & & & & & & & $\begin{array}{c}0.057 \\
{[0.510]} \\
-0.223 \\
{[0.207]}\end{array}$ & $\begin{array}{l}-0.037^{*} \\
{[0.076]} \\
-0.039 \\
{[0.147]}\end{array}$ & $\begin{array}{c}0.024 \\
{[0.557]} \\
-0.104^{* *} \\
{[0.041]}\end{array}$ \\
\hline $\begin{array}{l}\text { Diagnostic tests } \\
\text { Non-stationarity } \\
\text { Cross-sectional dependence }\end{array}$ & $\begin{array}{l}{[0.000]} \\
{[0.000]}\end{array}$ & $\begin{array}{l}{[0.000]} \\
{[0.000]}\end{array}$ & $\begin{array}{l}{[0.000]} \\
{[0.001]}\end{array}$ & $\begin{array}{l}{[0.000]} \\
{[0.000]}\end{array}$ & $\begin{array}{l}{[0.000]} \\
{[0.000]}\end{array}$ & $\begin{array}{l}{[0.000]} \\
{[0.000]}\end{array}$ & $\begin{array}{l}{[0.000]} \\
{[0.001]}\end{array}$ & $\begin{array}{l}{[0.000]} \\
{[0.000]}\end{array}$ & $\begin{array}{l}{[0.000]} \\
{[0.002]}\end{array}$ \\
\hline $\begin{array}{l}\text { Obs. } \\
\text { Parameters }\end{array}$ & 544 & $\begin{array}{c}544 \\
\text { Homogeneous }\end{array}$ & 2693 & 544 & $\begin{array}{c}544 \\
\text { Heterogeneous }\end{array}$ & 2693 & 544 & $\begin{array}{l}\quad 544 \\
\text { Heterogeneous }\end{array}$ & 2693 \\
\hline
\end{tabular}

Notes: The long-run parameters $(\theta)$ are derived from the ARDL specification (with logged variables) estimated with CMG. All regressions include country-specific fixed effects, country-specific time trends, and five lags of the variables. Piketty and Zucman (2014) express wealth at market prices, $s$ and $g$ in net values $\left(s^{N}\right.$ and $\left.g^{N}\right)$. Our data are expressed at constant prices and in gross terms $\left(s^{G}\right.$ and $\left.g^{G}\right)$; income growth is defined as $g^{G}=g^{N}+\delta$ with capital depreciation, $\delta$, set to 0.08. Diagnostic tests of the residuals. H0: panel non-stationarity/unit roots (Pesaran 2007). H0: weak panel cross-sectional dependence (Pesaran 2015). $p$-values in brackets. ${ }^{* * *},{ }^{* *},{ }^{*}$ indicate significance at 1,5 and $10 \%$, respectively. 
Thus far, the coefficients of $s$ and $g$ are restricted to be the same but of opposite sign. In the last three columns of Table 2, we regress the wealth-to-income ratio on the saving rate and on the rate of income growth, separately. Piketty and Zucman (2014) argue that, as long as the saving rate is constant over time, $\beta$ should respond to the acceleration or the deceleration in the rate of income growth, $g$. This view finds support in the estimates yielded using our dataset, but less so when relying upon their data. Probably due to small sample bias issues, the latter estimates do not achieve standard levels of significance, albeit they look correctly signed 11 To conclude, note that the null hypotheses of non-stationarity and crosssectional dependence of the residuals are rejected at conventional significance levels, thus giving support to our estimation framework 12

\section{Time Pattern and Capital Composition}

Next, we investigate whether the drivers of the wealth-income ratio have changed over time. The most advanced countries experienced the biggest increase in their productivity growth rates after WWII and this may have shaped the evolution of wealth-to-income inequality in recent decades (Madsen, 2010). To assess this issue, we estimate Eq. (5) over two distinct time intervals, namely 1870-1945 and 19452010 (Table 3), accounting for fully heterogeneous parameters and unobserved common shocks (CMG regression). In this step of the analysis we use only our data, as it is less parsimonious in terms of observations. The coefficients of the ratio between the saving rate and income growth remain significantly positive in both periods and their magnitudes are quite similar. When one seeks to identify the impact of the saving rate and that of income growth separately (cols. 4-6), the latter variable is found to play

\footnotetext{
${ }^{11}$ Excluding $g$ from the regressions (not shown) did not change the significance of $s$, suggesting that the insignificance of this variable is not driven by collinearity between $s$ and $g$ (for instance, in the AK model income growth is endogenously determined by the saving rate in the long run).

${ }_{12}$ Pesaran/s (2007) test assumes the null hypothesis that residuals contain unit roots, whilst Pesaran's (2015) test assumes that residuals are (weakly) cross-sectionally dependent. Rejection of both hypotheses guarantees the validity of the regression framework used. To further assess the extent to which our results are driven by the econometric procedure used, we re-estimated all the specifications in Table 2 using two alternative regression techniques. First, we estimated the pooled version of Eq. (5), augmented with CCE effects. These results are presented in Table B2 of Appendix B and are quite similar to the estimates in Table 2 Second, we adopted a different procedure to treat cross-sectional dependence based on the Augmented Mean Group (AMG) regression developed by Bond and Eberhardt (2013) (see Table B3 of Appendix B). The AMG regression estimates the specification of interest separately for each individual country including a common dynamic process term; the latter is inferred from the coefficients of the time dummies included in the pooled version of Eq. (5), estimated in first differences. The AMG procedure yields lower coefficients compared to results obtained by the fixed effect estimator with the CCE and the CMG regressions (Tables $\mathrm{B} 2$ and 2). However, it should be borne in mind that the AMG estimator has been designed for a static framework of analysis and hence it may not be perfectly suited to a dynamic specification like that used in the present work. To some extent, this caveat is corroborated by diagnostic tests which, in some specifications, detect non-stationarity of residuals. This imposes caution in interpreting AMG results and posits in favour of the estimates in Table 2
} 
a prominent role in the long-run evolution of wealth inequality. Puzzlingly, the absolute magnitude of the coefficient of income growth is estimated to be larger over the entire time span (i.e., 1870-2010) than in the separate time intervals, especially compared to the latest sample period when this explanatory variable turns out to be insignificant 13

Table 3: Relationship between $\beta$ and $s / g$ over time: 1870-1945 vs 1945-2010 (Our data) ARDL estimation (long-run heterogeneous parameters) - CMG

\begin{tabular}{|c|c|c|c|c|c|c|}
\hline & (1) & (2) & (3) & (4) & (5) & (6) \\
\hline & \multicolumn{6}{|c|}{$\begin{array}{c}\text { Total capital / GDP } \\
\text { Gross values }\left(s^{G} \text { and } g^{N}+\delta\right)\end{array}$} \\
\hline & $1870-2010$ & $1870-1945$ & $1945-2010$ & $1870-2010$ & $1870-1945$ & $1945-2010$ \\
\hline $\begin{array}{l}\text { Dependent Variable: } \ln \beta \\
\ln s / g\end{array}$ & $\begin{array}{c}0.069^{* * *} \\
{[0.004]}\end{array}$ & $\begin{array}{c}0.050^{* * *} \\
{[0.008]}\end{array}$ & $\begin{array}{c}0.066^{* *} \\
{[0.038]}\end{array}$ & & & \\
\hline $\begin{array}{l}\ln s \\
\ln g\end{array}$ & & & & $\begin{array}{c}0.024 \\
{[0.557]} \\
-0.104^{* *} \\
{[0.041]}\end{array}$ & $\begin{array}{c}0.027 \\
{[0.488]} \\
-0.050^{* * *} \\
{[0.019]}\end{array}$ & $\begin{array}{l}-0.018 \\
{[0.699]} \\
-0.024 \\
{[0.476]}\end{array}$ \\
\hline $\begin{array}{l}\text { Diagnostic tests } \\
\text { Non-stationarity } \\
\text { Cross-sectional dependence }\end{array}$ & $\begin{array}{l}{[0.000]} \\
{[0.000]}\end{array}$ & $\begin{array}{l}{[0.000]} \\
{[0.008]}\end{array}$ & $\begin{array}{l}{[0.000]} \\
{[0.002]}\end{array}$ & $\begin{array}{l}{[0.002]} \\
{[0.000]}\end{array}$ & $\begin{array}{l}{[0.000]} \\
{[0.899]}\end{array}$ & $\begin{array}{l}{[0.000]} \\
{[0.000]}\end{array}$ \\
\hline Obs. & 2,693 & 1,300 & 1,414 & 2,693 & 1,300 & 1,414 \\
\hline
\end{tabular}

Notes: The long-run parameters $(\theta)$ are derived from the ARDL specification (with logged variables) estimated with CMG. All regressions include country-specific fixed effects, country-specific time trends, five lags of the variables in the regression over the period 1870-2010, and four lags in the regressions over the periods 1870-1945 and 1945-2010. Our data are expressed at constant prices and in gross terms $\left(s^{G}\right.$ and $\left.g^{G}\right)$; income growth is defined as $g^{G}=g^{N}+\delta$ with capital depreciation, $\delta$, set to 0.08. Diagnostic tests of the residuals. H0: panel non-stationarity/unit roots $($ Pesaran 2007). H0: weak panel cross-sectional dependence (Pesaran 2015). $p$-values in brackets. ***,**,* indicate significance at 1,5 and $10 \%$, respectively.

Finally, we investigate whether changes in the capital (wealth) composition have been responsible for the puzzling result that, in the post WWII period, the (domestic) ratio between wealth and income has been unrelated to changes in saving and income growth (at home and abroad). In the first half of Table 4 we identify the impact of the saving rate and income growth on the accumulation of equipment and structures separately from 1945 to 2010 (both capital measures are expressed as a ratio to income). In the second half, we restrict the focus on the post-1970 period, which is central in Piketty and Zucman s (2014) discussion because it coincides with the reversal in anti-capitalistic policies implemented by most countries at this time. Both sets of estimates suggest that the insignificance of both explanatory variables on the total capital-to-income ratio may be due to the opposite effects of these regressors on the two capital types. This is particularly true for income growth, which has a negative and significant impact on the

\footnotetext{
${ }^{13}$ Similar results arise using $\overline{\text { Piketty and Zucman }} \mathrm{s}(2014)$ data.
} 
ratio between structures and income but a positive one on the ratio between equipment and income. The magnitude of the latter effect appears to be really important (0.743 and 0.692). Following the seminal paper by Greenwood et al. (1997), economic growth has been increasingly acknowledged to depend on technical advances embodied in machinery and equipment (Boucekkine et al., 2003, Venturini, 2007). Here, we find that income growth would have favoured accumulation of machinery and equipment, thus providing higher rents to the owners of such factor inputs.

Table 4: Relationship between $\beta$ and $s / g$ :

Machinery and equipment vs structures capital (Our data)

ARDL estimation (long-run heterogeneous parameters) - CMG

\begin{tabular}{|c|c|c|c|c|c|c|}
\hline & (1) & $(2)$ & $(3)$ & $(4)$ & $(5)$ & $(6)$ \\
\hline & \multicolumn{6}{|c|}{ Gross values $\left(s^{G}\right.$ and $\left.g^{N}+\delta\right)$} \\
\hline & & $1945-2010$ & & & $1970-2010$ & \\
\hline & $\begin{array}{c}\text { Total } \\
\text { capital/ } \\
\text { GDP }\end{array}$ & $\begin{array}{c}\text { Equip- } \\
\text { ment/ } \\
\text { GDP }\end{array}$ & $\begin{array}{l}\text { Struc- } \\
\text { tures/ } \\
\text { GDP }\end{array}$ & $\begin{array}{c}\text { Total } \\
\text { capital/ } \\
\text { GDP }\end{array}$ & $\begin{array}{c}\text { Equip- } \\
\text { ment/ } \\
\text { GDP }\end{array}$ & $\begin{array}{c}\text { Struc- } \\
\text { tures/ } \\
\text { GDP }\end{array}$ \\
\hline \multicolumn{7}{|l|}{ Dependent Variable: $\ln \beta$} \\
\hline \multirow[t]{2}{*}{$\ln s$} & -0.018 & $0.244^{* *}$ & $-0.261^{*}$ & 0.054 & 0.026 & $0.103^{*}$ \\
\hline & {$[0.699]$} & {$[0.048]$} & {$[0.068]$} & {$[0.464]$} & {$[0.902]$} & {$[0.098]$} \\
\hline \multirow[t]{2}{*}{$\ln g$} & -0.024 & $0.743^{* *}$ & -0.079 & -0.126 & $0.692^{*}$ & $-0.040^{*}$ \\
\hline & {$[0.476]$} & {$[0.048]$} & {$[0.141]$} & {$[0.226]$} & {$[0.059]$} & {$[0.094]$} \\
\hline \multicolumn{7}{|l|}{ Diagnostic tests } \\
\hline Non-stationarity & {$[0.000]$} & {$[0.000]$} & {$[0.000]$} & {$[0.000]$} & {$[0.000]$} & {$[0.000]$} \\
\hline Cross-sectional dependence & {$[0.000]$} & {$[0.282]$} & {$[0.000]$} & {$[0.557]$} & {$[0.791]$} & {$[0.077]$} \\
\hline Obs. & 1,338 & 1,344 & 1,344 & 861 & 861 & 861 \\
\hline
\end{tabular}

Notes: The long-run parameters $(\theta)$ are derived from the ARDL specification (with logged variables) estimated with CMG. All regressions include country-specific fixed effects, country-specific time trends, four lags in the regressions over the period 1870-1945 and three lags for 1945-2010. Our data are expressed at constant prices and in gross terms $\left(s^{G}\right.$ and $\left.g^{G}\right)$; income growth is defined as $g^{G}=g^{N}+\delta$ with capital depreciation, $\delta$, set to 0.08 for total capital, to 0.17 for equipment and to 0.03 for structures. Diagnostic tests of the residuals. H0: panel non-stationarity/unit roots (Pesaran. 2007). H0: weak panel cross-sectional dependence (Pesaran 2015). $p$-values in brackets. ***,**,* indicate significance at 1,5 and $10 \%$, respectively.

\section{Discussion and Final Remarks}

In this paper we have performed a long-run analysis of wealth inequality using both Piketty and Zucman's (2014) original data and a new long historical dataset covering 21 OECD countries. We show that the path followed by the wealth-to-income ratio, $\beta$, has been driven by variation in the $s / g$ ratio between 1870 and 2010, albeit $\beta$ responds less than proportionally to these changes in $s / g$. Furthermore, we have documented that the wealth-to-income ratio over the very long run (1870-2010) responds to the 
variations in income growth much more than to variations in the saving rate. However, this pattern may have changed in recent decades as the impact of $g$ varies with the capital composition and the nature of these assets. Income growth is found to be negatively related to the ratio between structures and income, but positively related to the ratio between equipment and income.

The opposite effects of $g$ on these two types of capital have very important implications for the evolution of wealth inequality. As long as the share of equipment in total capital continues to increase over time, and this component of wealth is positively related to the rate of economic expansion, policies aimed at reversing the secular stagnation in labour productivity growth may not impact on wealth inequality. This casts doubts on the effectiveness of growth-enhancing policies as self-contained instruments for reducing income disparities between capital and labour. However, if the current low rates of productivity growth persist over time (or even slow down further), and the ratio of firms' investment between structures and equipment does not change, the wealth-to-income ratio could level off, i.e., wealth inequality might not increase despite the ongoing productivity slowdown. From this point of view, our attempt to examine heterogeneity in capital composition is very instructive for predicting the future evolution of wealth inequality under different growth scenarios.

Finally, since machinery and equipment capital are increasingly important conduits of technical change in the economy, our findings suggest that the inequality effects of investment-specific technological change are not limited to the labour market, due to the increasing wage differentials between skilled and unskilled workers (i.e., within inequality), but they also widen inequality between factors of production, i.e., through the capital-to-income ratio (see Hornstein et al., 2005).

\section{Acknowledgments}

Helpful comments and suggestions by participants at the 5th AMSE Workshop on Growth and Development (Marseille, 2015), Meeting of the Association of Southern European Economic Theorists in Granada, 2015, and seminars at the University of Perugia and Middlesex Business School, Thomas Piketty, Michela Vecchi, and, particularly, Frances Teal (editor) and two referees are gratefully acknowledged. 


\section{Funding}

This work was supported by the Australian Research Council [grant numbers DP170100339 and DP150100061 to J.B.M.]. 


\section{References}

Acemoglu, D. and Robinson, J. A. (2015). The Rise and Decline of General Laws of Capitalism. Journal of Economic Perspectives, 29(1):3-28.

Barro, R. and Sala-i-Martin, X. (2004). Economic Growth. MIT Boston, Second Edition.

Bassanini, A. and Manfredi, T. (2014). Capital's Grabbing Hand? A Cross-Country/Cross-Industry Analysis of the Decline of the Labour Share. Eurasian Business Review, 4(1):3-30.

Bond, S. and Eberhardt, M. (2013). Accounting for Unobserved Heterogeneity in Panel Time Series Models. Nuffield College, University of Oxford, mimeo.

Bond, S., Leblebicioglu, A., and Schiantarelli, F. (2010). Capital Accumulation and Growth: A New Look at the Empirical Evidence. Journal of Applied Econometrics, 25(7):1073-1099.

Bonnet, O., Bono, P.-H., Chapelle, G., and Wasmer, E. (2014). Does Housing Capital Contribute to Inequality? A Comment on Thomas Piketty's Capital in the 21st Century. Technical Report 2014-07, Sciences Po, Département d'Économie.

Boucekkine, R., del Rio, F., and Licandro, O. (2003). Embodied Technological Change, Learning-by-doing and the Productivity Slowdown. Scandinavian Journal of Economics, 105(1):87-98.

Cerrato, M., de Peretti, C., Larsson, R., and Sarantis, N. (2011). 'A Non-Linear Panel Unit Root Test under Cross Section Dependence'. Working Papers 2011-08 9581, Business School - Economics, University of Glasgow.

Checchi, D. and García-Peñalosa, C. (2010). Labour Market Institutions and the Personal Distribution of Income in the OECD. Economica, 77(307):413-450.

Chudik, A., Mohaddes, K., Pesaran, M. H., and Raissi, M. (2016). Long-Run Effects in Large Heterogenous Panel Data Models with Cross-Sectionally Correlated Errors. University of Cambridge, mimeo.

Chudik, A. and Pesaran, M. H. (2015). Common Correlated Effects Estimation of Heterogeneous Dynamic Panel Data Models with Weakly Exogenous Regressors. Journal of Econometrics, 188(2):393-420.

Eberhardt, M., Helmers, C., and Strauss, H. (2013). Do Spillovers Matter When Estimating Private Returns to R\&D? The Review of Economics and Statistics, 95(2):436-448. 
Eberhardt, M. and Presbitero, A. F. (2015). Public Debt and Growth: Heterogeneity and Non Linearity. Journal of International Economics, 97(1):45-58.

Eberhardt, M. and Teal, F. (2011). Econometrics for Grumblers: A New Look at the Literature on Country country Growth Empirics. Journal of Economic Surveys, 25(1):109-155.

Goes, C. (2016). Testing Piketty's Hypothesis on the Drivers of Income Inequality: Evidence from Panel VAR heteregenous Dynamics. IMF Working Papers 16/160, International Monetary Fund.

Greenwood, J., Hercowitz, Z., and Krusell, P. (1997). Long-Run Implications of Investment-Specific Technological Change. American Economic Review, 87(3):342-62.

Hornstein, A., Krusell, P., and Violante, G. L. (2005). The Effects of Technical Change on Labor Market Inequalities. In Aghion, P. and Durlauf, S., editors, Handbook of Economic Growth, volume 1, chapter 20, pages 1275-1370. Elsevier, Amsterdam.

Jones, C. I. (2015). Pareto and Piketty: The Macroeconomics of Top Income and Wealth Inequality. Journal of Economic Perspectives, 29(1):29-46.

Karabarbounis, L. and Neiman, B. (2014). The Global Decline of the Labor Share. The Quarterly Journal of Economics, 129(1):61-103.

Krusell, P. and Smith, T. (2015). Is Piketty's Second Law of Capitalism Fundamental? Journal of Political Economy, 123(4):725-748.

Madsen, J. B. (2010). The anatomy of growth in the OECD since 1870. Journal of Monetary Economics, $57(6): 753-767$.

Madsen, J. B. (2016). 'Wealth and Inequality in Eight Century of British Capitalism'. Research Discussion Paper 20-16, Department of Economics, Monash Univesity.

Mankiw, G. (2015). Yes, r>g. So What? American Economic Review, Papers and Proceedings, 105(5):4347.

Milanovic, B. (2014). The Return of Patrimonial Capitalism: A Review of Thomas Piketty's Capital in the Twenty-First Century. Journal of Economic Literature, 52(2):519-34. 
Peretto, P. F. (2015). From Smith to Schumpeter: A Theory of Take-off and Convergence to Sustained Growth. European Economic Review, 78:1-26.

Peretto, P. F. and Seater, J. J. (2013). Factor-eliminating Technical Change. Journal of Monetary Economics, 60(4):459-473.

Pesaran, M. H. (2006). Estimation and Inference in Large Heterogeneous Panels with a Multifactor Error Structure. Econometrica, 74(4):967-1012.

Pesaran, M. H. (2007). A Simple Panel Unit Root Test in the Presence of Cross-section Dependence. Journal of Applied Econometrics, 22(2):265-312.

Pesaran, M. H. (2015). Testing Weak Cross-Sectional Dependence in Large Panels. Econometric Reviews, 34(6-10):1089-1117.

Pesaran, M. H. and Shin, Y. (1999). An Autoregressive Distributed Lag Modelling Approach to Cointegration Analysis. In Strøm, S., editor, Econometrics and Economic Theory in the 20th Century: The Ragnar Frisch Centennial Symposium, chapter 11, pages 371-413. Cambridge University Press, Cambridge.

Pesaran, M. H. and Smith, R. (1995). Estimating Long-run Relationships from Dynamic Heterogeneous Panels. Journal of Econometrics, 68(1):79-113.

Piketty, T. (2014). Capital in the Twenty-First Century. Harvard University Press, Cambridge and London.

Piketty, T. and Zucman, G. (2014). Capital is Back: Wealth-Income Ratios in Rich Countries, 1700-2010. Quarterly Journal of Economics, 123(3):1155-1210.

Roine, J., Vlachos, J., and Waldenström, D. (2009). The Long-Run Determinants of Inequality: What Can We Learn from Top Income Data? Journal of Public Economics, 93(7-8):974-988.

Saez, E. and Zucman, G. (2016). Wealth Inequality in the United States since 1913: Evidence from Capitalized Income Tax Data. The Quarterly Journal of Economics, 131(2):519-578.

Solow, R. M. (2014). Thomas Piketty is Right. The New Republic, 1-12, April 23, available at: http://newrepublic.com/article/117429/capital-twenty-first-century-thomas-piketty-reviewed. 
Sturgill, B. (2012). The Relationship Between Factor Shares and Economic Development. Journal of Macroeconomics, 34(4):1044-1062.

Sturgill, B. (2014). Back to the Basics: Revisiting the Development Accounting Methodology. Journal of Macroeconomics, 42(C):52-68.

Venturini, F. (2007). ICT and Productivity Resurgence: A Growth Model for the Information Age. The B.E. Journal of Macroeconomics, 7(1):1-26.

Weil, D. (2015). Capital and Wealth in the 21st Century. American Economic Review, Papers and Proceedings, 105(5):34-37. 


\section{Appendix}

\section{A The AK Model}

In this Appendix, we show that the formula $\beta=s / g$ holds in the AK endogenous growth model with optimizing consumers (see Barro and Sala-i-Martin 2004, ch. 4, pp. 205-211). More precisely, we first prove that (i) in the textbook model (with variables expressed in gross terms) the capital-income ratio amounts to $K / \hat{Y}=\hat{s} /(g+\delta)$. We then show that (ii) this equation is mathematically equivalent to Piketty's formulation, $K / Y=s / g$, where $Y \equiv \hat{Y}-\delta K$ is net output, $s \equiv \dot{K} /(\hat{Y}-\delta K)$ is the net saving rate, and $g$ is the growth rate of GDP (inclusive of population growth).

(i) Proof that $K / \hat{Y}=\hat{s} /(g+\delta)$

The capital-income ratio amounts to $K / \hat{Y}=1 / A$, the per capita growth rate is equal to $g^{\prime}=(A-\delta-\rho) / \theta$, and the gross saving rate is given by

$$
\hat{s} \equiv \frac{\dot{K}+\delta K}{\hat{Y}}=\frac{A-\rho+\theta n+(\theta-1) \delta}{\theta A},
$$

where $\rho$ denotes the discount rate and $\theta>0$ is the reciprocal of the elasticity of intertemporal substitution for the constant intertemporal elasticity of substitution (CIES) utility function. Since $g \equiv g^{\prime}+n$, using the previous results, it is easy to prove that

$$
\begin{aligned}
\frac{\hat{s}}{g+\delta} & =\frac{A-\rho+\theta n+(\theta-1) \delta}{\theta A\left[\frac{A-\delta-\rho}{\theta}+\delta+n\right]} \\
& =\frac{A-\rho+\theta n+(\theta-1) \delta}{A[A-\rho+\theta n+(\theta-1) \delta]} \\
& =\frac{1}{A} \\
& =\frac{K}{\hat{Y}} .
\end{aligned}
$$

(ii) Proof that $K / Y=s / g$

The ratio between capital and net income amounts to

$$
\frac{K}{Y} \equiv \frac{K}{\hat{Y}-\delta K}=\frac{1}{A-\delta}
$$


Using the fact that capital and income grow at the same rate, namely $\dot{K} / K=\dot{Y} / Y=g=\frac{A-\delta-\rho}{\theta}+n$, the net saving rate can be expressed as

$$
\begin{aligned}
s \equiv \frac{\dot{K}}{\hat{Y}-\delta K} & =\frac{\dot{K} / K}{\hat{Y} / K-\delta} \\
& =\frac{\frac{A-\delta-\rho}{\theta}+n}{A-\delta} \\
& =\frac{A-\delta-\rho+\theta n}{\theta(A-\delta)} .
\end{aligned}
$$

We then use these equations to prove that

$$
\begin{aligned}
\frac{s}{g} & =\frac{A-\delta-\rho+\theta n}{\theta(A-\delta)\left[\frac{A-\delta-\rho}{\theta}+n\right]} \\
& =\frac{A-\delta-\rho+\theta n}{(A-\delta)[A-\delta-\rho+\theta n]} \\
& =\frac{1}{A-\delta} \\
& =\frac{K}{Y} .
\end{aligned}
$$




\section{B Tables}

Table B1: Panel unit roots on $\beta$ and $s / g:$ 1870-2010

\begin{tabular}{|c|c|c|c|c|c|c|}
\hline & $(1)$ & $(2)$ & $(3)$ & $(4)$ & $(5)$ & $(6)$ \\
\hline & \multicolumn{2}{|c|}{ Piketty \& Zucman's data } & Our data & \multicolumn{2}{|c|}{ Piketty \& Zucman's data } & Our data \\
\hline & $\begin{array}{c}\text { National } \\
\text { wealth/ } \\
\text { Income } \\
\text { (Net) } \\
s^{N} / g^{N}\end{array}$ & $\begin{array}{c}\text { Private } \\
\text { wealth/ } \\
\text { Income } \\
\text { (Net) } \\
s^{N} / g^{N}\end{array}$ & $\begin{array}{c}\text { Total } \\
\text { capital } \\
\text { GDP } \\
(\text { Gross }) \\
s^{G} /\left(g^{N}+\delta\right)\end{array}$ & $\begin{array}{c}\text { National } \\
\text { wealth/ } \\
\text { Income } \\
\text { (Net) } \\
s^{N} / g^{N}\end{array}$ & $\begin{array}{c}\text { Private } \\
\text { wealth/ } \\
\text { Income } \\
\text { (Net) } \\
s^{N} / g^{N}\end{array}$ & $\begin{array}{c}\text { Total } \\
\text { capital/ } \\
\text { GDP } \\
(\text { Gross }) \\
s^{G} /\left(g^{N}+\delta\right)\end{array}$ \\
\hline \multicolumn{7}{|c|}{ Linear Panel CADF - Pesaran (2007) } \\
\hline $\begin{array}{l}\ln \beta \\
\ln s / g \\
\ln s \\
\ln g\end{array}$ & $\begin{array}{c}-16.129^{* * *} \\
-4.771^{* * *}\end{array}$ & $\begin{array}{c}-15.078^{* * *} \\
-7.753^{* * *}\end{array}$ & $\begin{array}{l}-2.983^{* * *} \\
-5.112^{* * *}\end{array}$ & $\begin{array}{l}-16.129^{* * *} \\
-4.196^{* * *} \\
-5.407^{* * *}\end{array}$ & $\begin{array}{c}-15.078^{* * *} \\
-5.115 \\
-5.407^{* * *}\end{array}$ & $\begin{array}{c}-2.983^{* * *} \\
-2.706^{*} \\
-8.821^{* * *}\end{array}$ \\
\hline \multicolumn{7}{|c|}{ Non-Linear Panel CADF - Cerrato et al. (2011) } \\
\hline $\begin{array}{l}\ln \beta \\
\ln s / g \\
\ln s \\
\ln g\end{array}$ & $\begin{array}{c}-14.071^{* * *} \\
-3.787^{* * *}\end{array}$ & $\begin{array}{l}-9.935^{* * *} \\
-5.222^{* * *}\end{array}$ & $\begin{array}{l}-2.646^{* * *} \\
-4.994^{* * *}\end{array}$ & $\begin{array}{l}-14.071^{* * *} \\
-3.541^{* * *} \\
-11.034^{* * *}\end{array}$ & $\begin{array}{l}-9.935^{* * *} \\
-4.542^{* * *} \\
-11.034^{* * *}\end{array}$ & $\begin{array}{l}-2.646^{* * *} \\
-2.373^{* * *} \\
-7.715^{* * *}\end{array}$ \\
\hline
\end{tabular}

Notes: H0: all units contain panel unit roots. Linear panel CADF Critical values. Cols 1-2 and 4-5: -3.03 (1\%), -2.83 (5\%), -2.73 (10\%). Cols 3 and 6: $-2.85(1 \%),-2.70(5 \%),-2.63(10 \%)$. Non-linear panel CADF Critical values. Cols 1-2 and 4-5: $-2.50(1 \%),-2.33(5 \%),-2.25(10 \%)$. Cols 3 and 6 : $-2.26(1 \%),-2.13(5 \%),-2.06(10 \%)$. $* * * * * *$ indicate significance at 1,5 and $10 \%$, respectively. 
Table B2: Relationship between $\beta$ and $s / g:$ 1870-2010

ARDL estimation (long-run homogeneous parameters) - CEE-FE

\begin{tabular}{|c|c|c|c|c|c|c|}
\hline & (1) & $(2)$ & $(3)$ & $(4)$ & $(5)$ & (6) \\
\hline & \multicolumn{2}{|c|}{ Piketty \& Zucman's data } & Our data & \multicolumn{2}{|c|}{ Piketty \& Zucman's data } & Our data \\
\hline & $\begin{array}{l}\text { National } \\
\text { wealth/ } \\
\text { Income } \\
\text { (Net) } \\
s^{N} / g^{N}\end{array}$ & $\begin{array}{c}\text { Private } \\
\text { wealth/ } \\
\text { Income } \\
\text { (Net) } \\
s^{N} / g^{N}\end{array}$ & $\begin{array}{c}\text { Total } \\
\text { capital } \\
\text { GDP } \\
(\text { Gross }) \\
s^{G} /\left(g^{N}+\delta\right)\end{array}$ & $\begin{array}{l}\text { National } \\
\text { wealth/ } \\
\text { Income } \\
\text { (Net) } \\
s^{N} / g^{N}\end{array}$ & $\begin{array}{c}\text { Private } \\
\text { wealth/ } \\
\text { Income } \\
\text { (Net) } \\
s^{N} / g^{N}\end{array}$ & $\begin{array}{c}\text { Total } \\
\text { capital/ } \\
\text { GDP } \\
(\text { Gross }) \\
s^{G} /\left(g^{N}+\delta\right)\end{array}$ \\
\hline $\begin{array}{l}\text { Dependent Variable: } \ln \beta \\
\ln s / g\end{array}$ & $\begin{array}{c}0.078^{* * *} \\
{[0.007]}\end{array}$ & $\begin{array}{c}0.035^{* *} \\
{[0.030]}\end{array}$ & $\begin{array}{c}0.071^{* * *} \\
{[0.000]}\end{array}$ & & & \\
\hline $\begin{array}{l}\ln s \\
\ln g\end{array}$ & & & & $\begin{array}{c}0.083 \\
{[0.11]} \\
-0.182^{* * *} \\
{[0.005]}\end{array}$ & $\begin{array}{c}-0.017 \\
{[0.204]} \\
-0.041^{* *} \\
{[0.010]}\end{array}$ & $\begin{array}{c}0.016 \\
{[0.414]} \\
-0.086^{* * *} \\
{[0.000]}\end{array}$ \\
\hline $\begin{array}{l}\text { Diagnostic tests } \\
\text { Non-stationarity } \\
\text { Cross-sectional dependence }\end{array}$ & $\begin{array}{l}{[0.028]} \\
{[0.000]}\end{array}$ & $\begin{array}{l}{[0.000]} \\
{[0.000]}\end{array}$ & $\begin{array}{l}{[0.001]} \\
{[0.000]}\end{array}$ & $\begin{array}{l}{[0.000]} \\
{[0.000]}\end{array}$ & $\begin{array}{l}{[0.005]} \\
{[0.000]}\end{array}$ & $\begin{array}{l}{[0.021]} \\
{[0.000]}\end{array}$ \\
\hline Obs. & 544 & 544 & 2,693 & 544 & 544 & 2,693 \\
\hline
\end{tabular}

Notes: The long-run parameters $(\theta)$ are derived from the ARDL specification (with logged variables) estimated using Fixed Effect estimator augmented with CCE (Pesaran 2006). All regressions include country-specific fixed effects, country-specific time trends, and five lags of the variables. Piketty and Zucman (2014) express wealth at market prices, $s$ and $g$ in net values $\left(s^{N}\right.$ and $\left.g^{N}\right)$. Our data are expressed at constant prices and in gross terms $\left(s^{G}\right.$ and $\left.g^{G}\right)$; income growth is defined as $g^{G}=g^{N}+\delta$ with capital depreciation, $\delta$, set to 0.08. Diagnostic tests of the residuals. H0: panel non-stationarity/unit roots (Pesaran 2007). H0: weak panel cross-sectional dependence (Pesaran 2015). p-values in brackets. ***, **, * indicate significance at 1,5 and $10 \%$, respectively. 
Table B3: Relationship between $\beta$ and $s / g:$ 1870-2010

ARDL estimation (long-run heterogeneous parameters) - AMG

\begin{tabular}{|c|c|c|c|c|c|c|}
\hline & (1) & $(2)$ & $(3)$ & (4) & $(5)$ & $(6)$ \\
\hline & \multicolumn{2}{|c|}{ Piketty \& Zucman's data } & Our data & \multicolumn{2}{|c|}{ Piketty \& Zucman's data } & Our data \\
\hline & $\begin{array}{c}\text { National } \\
\text { wealth/ } \\
\text { Income } \\
\text { (Net) } \\
s^{N} / g^{N}\end{array}$ & $\begin{array}{c}\text { Private } \\
\text { wealth/ } \\
\text { Income } \\
\text { (Net) } \\
s^{N} / g^{N}\end{array}$ & $\begin{array}{c}\text { Total } \\
\text { capital } \\
\text { GDP } \\
(\text { Gross }) \\
s^{G} /\left(g^{N}+\delta\right)\end{array}$ & $\begin{array}{c}\text { National } \\
\text { wealth/ } \\
\text { Income } \\
\text { (Net) } \\
s^{N} / g^{N}\end{array}$ & $\begin{array}{c}\text { Private } \\
\text { wealth/ } \\
\text { Income } \\
\text { (Net) } \\
s^{N} / g^{N}\end{array}$ & $\begin{array}{c}\text { Total } \\
\text { capital/ } \\
\text { GDP } \\
\text { (Gross) } \\
s^{G} /\left(g^{N}+\delta\right)\end{array}$ \\
\hline $\begin{array}{l}\text { Dependent Variable: } \ln \beta \\
\ln s / g\end{array}$ & $\begin{array}{c}0.025 \\
{[0.248]}\end{array}$ & $\begin{array}{c}0.026 \\
{[0.304]}\end{array}$ & $\begin{array}{c}0.044 \\
{[0.147]}\end{array}$ & & & \\
\hline $\ln s$ & & & & $\begin{array}{c}0.024^{* * *} \\
{[0.004]}\end{array}$ & $\begin{array}{c}0.052 \\
{[0.471]}\end{array}$ & $\begin{array}{c}0.014 \\
{[0.655]}\end{array}$ \\
\hline $\ln g$ & & & & $\begin{array}{c}-0.037 * * * \\
{[0.002]}\end{array}$ & $\begin{array}{l}-0.052 \\
{[0.540]}\end{array}$ & -0.046 \\
\hline Diagnostic tests & & & & & & \\
\hline Non-stationarity & {$[0.028]$} & {$[0.045]$} & {$[0.000]$} & {$[0.107]$} & {$[0.005]$} & {$[0.000]$} \\
\hline Cross-sectional dependence & {$[0.000]$} & {$[0.000]$} & {$[0.000]$} & {$[0.001]$} & {$[0.000]$} & {$[0.000]$} \\
\hline Obs. & 544 & 544 & 2,693 & 544 & 544 & 2,693 \\
\hline
\end{tabular}

Notes: The long-run parameters $(\theta)$ are derived from the ARDL specification (with logged variables) estimated with Augmented Mean Group (Bond and Eberhardt 2013). All regressions include country-specific fixed effects, country-specific time trends, and five lags of the variables. Piketty and Zucman (2014) express wealth at market prices, $s$ and $g$ in net values $\left(s^{N}\right.$ and $\left.g^{N}\right)$. Our data are expressed at constant prices and in gross terms $\left(s^{G}\right.$ and $g^{G}$ ); income growth is defined as $g^{G}=g^{N}+\delta$ with capital depreciation, $\delta$, set to 0.08. Diagnostic tests of the residuals. H0: panel non-stationarity/unit roots (Pesaran, 2007). H0: weak panel cross-sectional dependence (Pesaran, 2015). p-values in brackets. ***, **, * indicate significance at 1,5 and $10 \%$, respectively. 